\title{
Photo Essay: Bringing Acupuncture to the People
}

\section{Tolbert Small in China and California}

\author{
Eana Meng | ORCID: 0000-0002-3667-6585 \\ Harvard Medical School, Boston, MA, USA | Department of History \\ of Science, Harvard University, Cambridge, MA, USA \\ eanameng@hms.harvard.edu
}

\begin{abstract}
This photo essay examines key events in the career of physician-activist Tolbert Small, a doctor for the Black Panther Party and one of the first American doctors to practice acupuncture. It features the historic 1972 Black Panther Party delegation to China where Small first learned about acupuncture, as well as the Harriet Tubman Medical Office where he incorporated acupuncture into his practice.
\end{abstract}

\section{Keywords}

Tolbert Small - Black Panther Party - China - Harriet Tubman Medical Office - acupuncture

Physician-activist Tolbert Small was formerly a doctor for the Black Panther Party (BРP) from 1970 to 1974 and served as medical director of the Party's sickle cell anemia outreach program. He was also one of the first American doctors to practice acupuncture. Since January 2019, I have been working with Small and others to preserve his personal archives. This photo essay provides a glimpse into this rich documentary trove, which includes records of key events in Small's career. ${ }^{1}$ It features his participation in the 1972 B PP delegation to the

1 All photographs here are reproduced with the permission of Tolbert Small. Additionally, Figures 3 and 4 are reproduced with the permission of Wendi Sue, Figure 10 is reproduced with the permission of David Bacon, and Figures 12, 15, and 16 are reproduced with the permission of Anola Price Small. The author has made all reasonable efforts to trace all rights 
People's Republic of China (PRC) where he first learned about acupuncture, as well as his dissemination of acupuncture knowledge at the BPP's George Jackson People's Free Medical Clinic in Berkeley, California, and at the Harriet Tubman Medical Office in Oakland, California, which he cofounded with Anola Price Small in 1980. He has been practicing acupuncture since 1972. For more details on Small's life and the historical value of his archives, see the accompanying interview and essay in this special issue. ${ }^{2}$

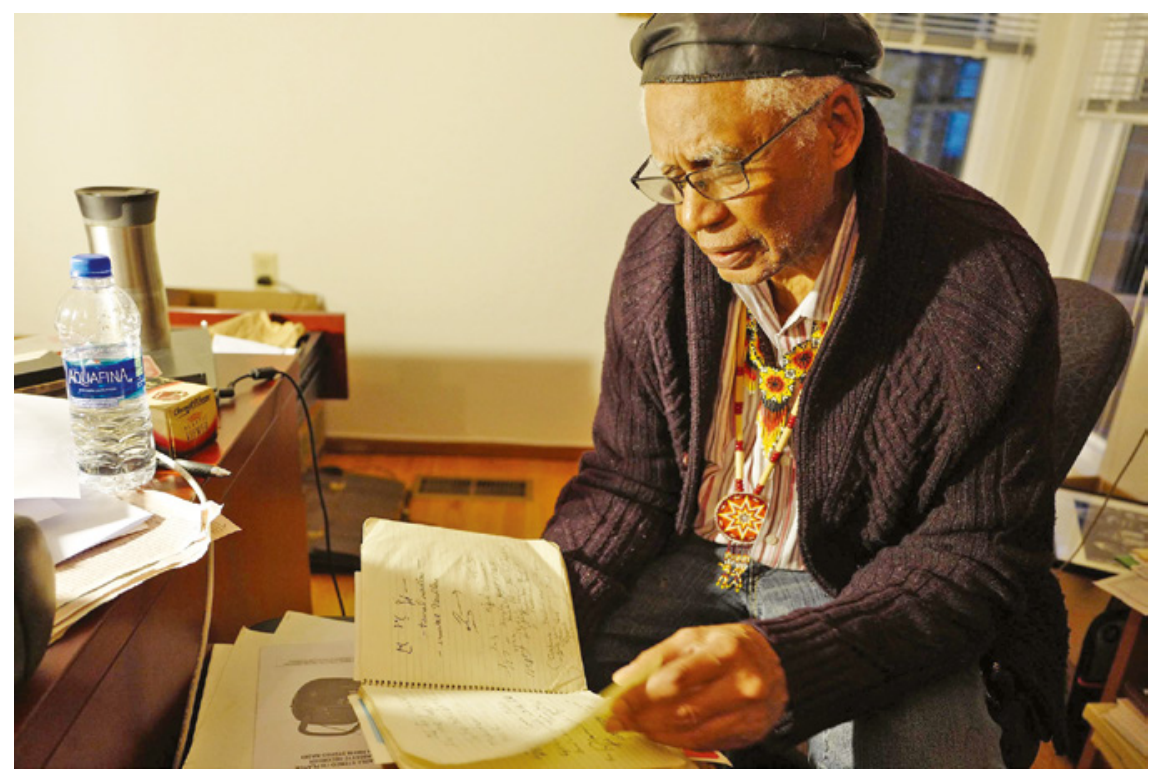

FIGURE 1 February 9, 2019: Tolbert Jones Small in his home in Oakland, California. Small worked with the B Р P from 1970 to 1974 . Wearing the signature Panther black beret, Small is showing the author a journal from his seven-week trip with a BPP delegation to the PRC, from March to April 1972. Other materials from his personal archive of the delegation include newspaper clippings, audio tapes, projector slides, photos, and books.

PHOTO TAKEN BY THE AUTHOR ON ABOVE DATE

holders to any copyrighted material used in this work. In cases where these efforts have not been successful the publisher welcomes communications from copyright holders, so that the appropriate acknowledgments can be made in future editions, and to settle other permission matters.

2 Burton-Rose and Wu 2021; Meng 2021. 


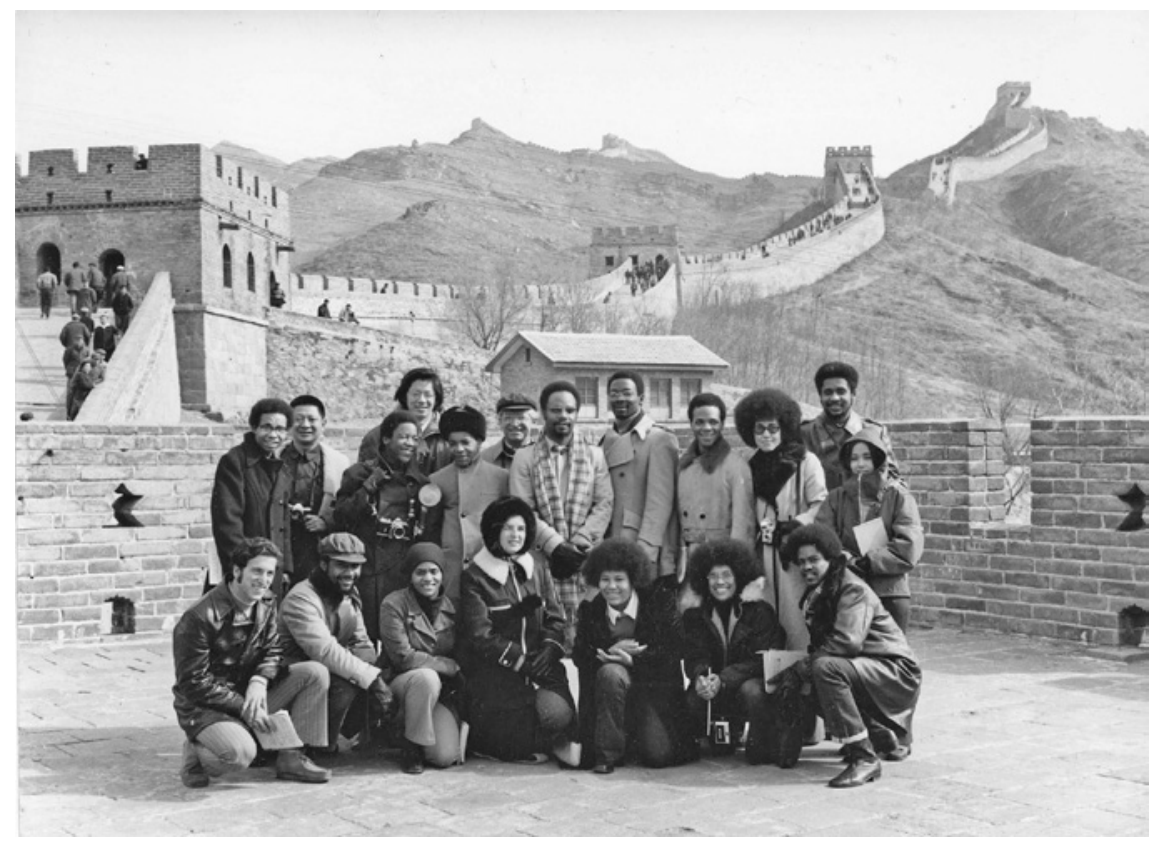

FIGURE 2 March 19, 1972: The BPP delegation at the stretch of the Great Wall north of Beijing. They arrived in Beijing on March 9, and spent many days in workshops, hospitals, schools, and cultural sites, hosted and accompanied by a number of tour guides from the Chinese Communist Party (CCP). On this day, they visited the Great Wall in the morning, and then the Ming Tombs in the afternoon. This photograph of the delegates later appeared in the B PP's official newspaper, The Black Panther Intercommunal News Service, on April 22, 1972, accompanying a report on the delegation's experiences titled "Progressive Americans, Led by Panthers, Return from China."

Kneeling, left to right: David Levinson, Mike Cross, Audrea Jones, Miriam Cherry, Rochella Hilliard, Edna Nelson, and Harold Holmes.

Standing, left to right: Ron Haynes, Ed Sue, Teddy Hill, William Seid, Dennis Litzsey Hilliard, Allen Brotsky, Emory Douglas, Raymond “Masai” Hewitt, Ronald "Doc" Satchel, Marie Branch, Small, and Mari Gushi.

Maurice Powell, the twentieth delegate on the trip, is not shown in this photo. Delegates who appear in additional photographs are further described below. All black-and-white photos appearing in this essay were taken by the CCP tour guides. A stack of roughly twenty photos was given to each delegate at the end of the trip.

Note: The delegates in this photo were identified by Small and Billy X. Jennings, a former ВРР member who collects and manages an extensive archive of вРР historical materials. Small and Jennings, in individual conversations with the author, October $5,2020$. 


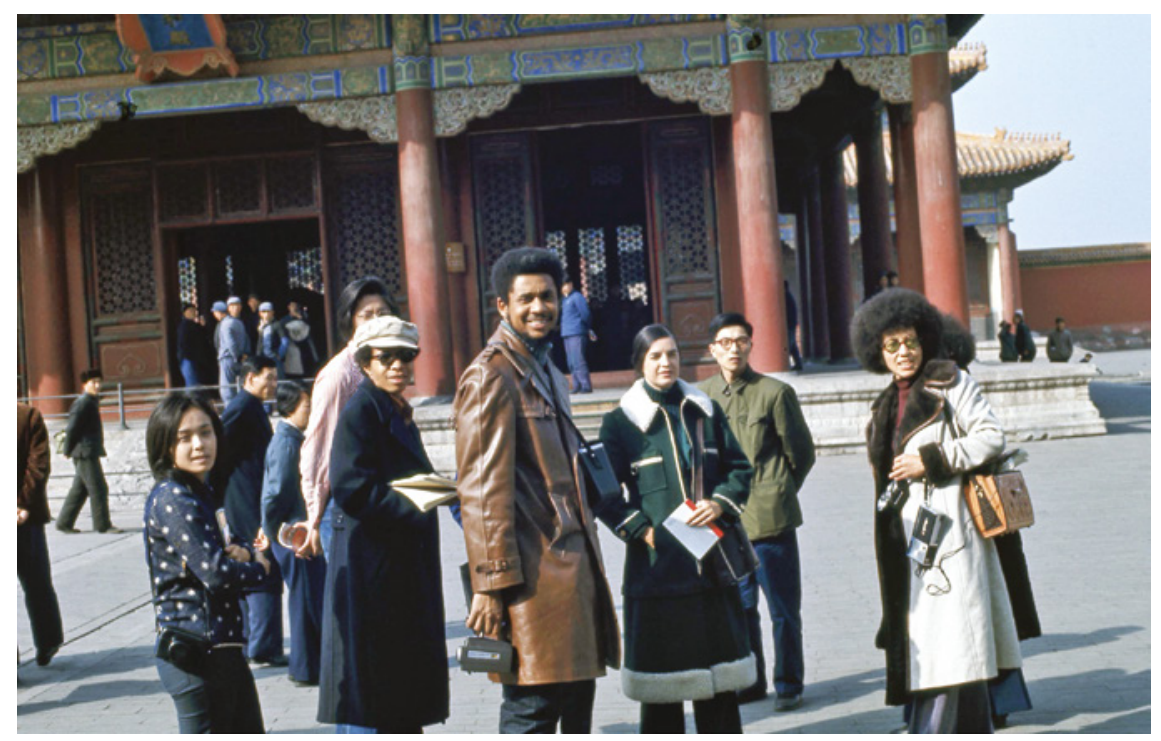

FIGURE 3 March 2o, 1972: In Beijing, near the Hall of Prayer for Good Harvests (Qiniandian 祈年殿) in the Temple of Heaven (Tiantan 天壇). They also visited Tiananmen Square on this last day in Beijing before departing for Yan'an the next morning. Small is in the center, with a video recorder in his right hand. His recordings are now being digitized.

From left to right: Gushi (dark spotted jacket), Haynes (tan cap), Small, Cherry (dark coat with white trim), unidentified translator for the delegation (army green coat and glasses), and Branch (light coat). At the time this photograph was taken, Gushi was a high school teacher in Los Angeles; Haynes, a math major at the University of California, Berkeley; ${ }^{a}$ Cherry, an associate chaplain at Stanford University who was previously part of the Venceremos organization and later joined the Intercommunal Survival Committee to Combat Fascism; b and Branch, a registered nurse. Branch later assisted with the B PP's free medical clinics in Los Angeles and was the private nurse to Elaine Brown, chairwoman of the BPP in Oakland (1974-77), during the birth of Brown's daughter. ${ }^{\mathrm{c}}$ This photo was taken by delegate Ed Sue (1941-2020), a Chinese American architect and Presbyterian minister whose projects included the Pacific Renaissance Plaza and the Oakland Asian Cultural Center in Oakland, California. Socially active and sympathetic to the Black revolutionary movement, Sue had become the chairman of the Office of Ethnic and Urban Affairs of the Presbyterian Church, where he raised money for Angela Davis and met a number of в рP leaders, including Huey Newton and Bobby Seale. Newton asked Sue to be part of the China delegation. ${ }^{\mathrm{d}}$

Notes:

a This information on Gushi and Haynes was provided by Small and Jennings.

b See Atkins 1972.

c See "A Taste of Power" 2015.

d Wendi Sue, in conversation with the author, October 14, 2020. Wendi Sue is the daughter of Ed Sue. 


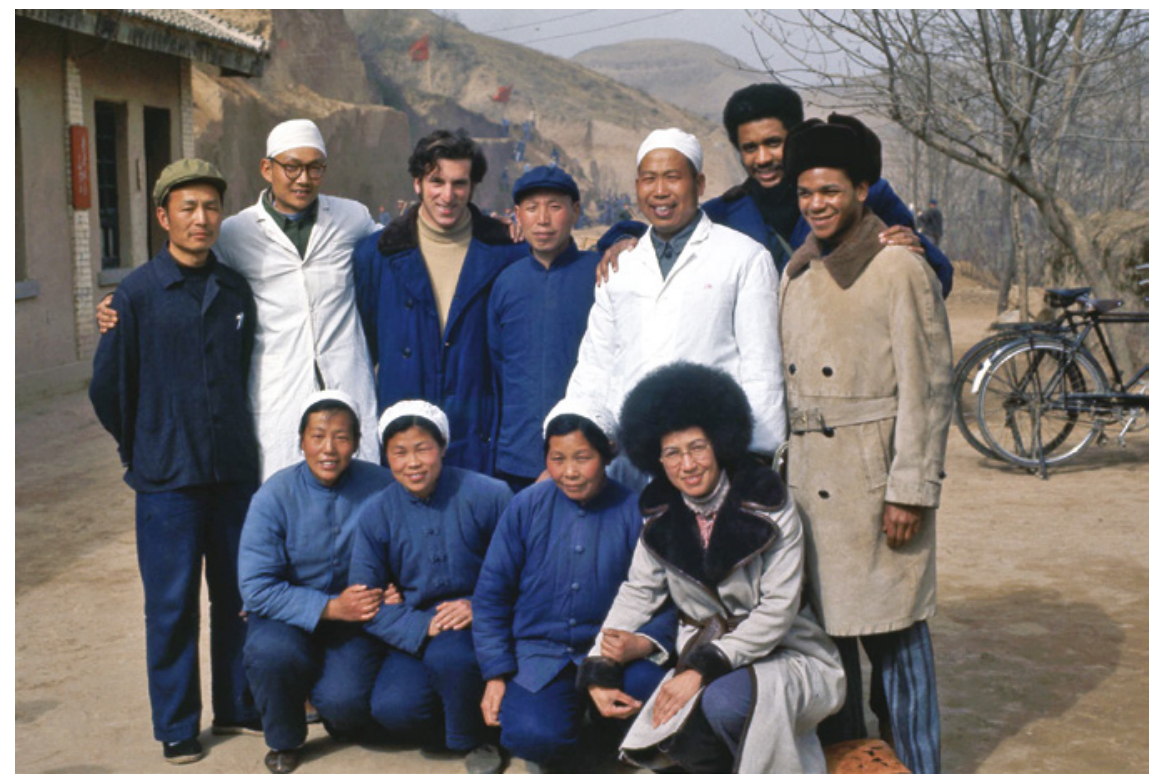

FIGURE 4 March 22, 1972: Members of the BPP delegation with barefoot doctors near Nanniwan 南泥灣, a gorge ninety kilometers southeast of Yan'an in Shaanxi Province. The group was given a number of presentations on the healthcare aspect of the revolution in the PRC. As the barefoot doctors movement particularly interested the delegates, their Chinese guides arranged a number of additional question-and-answer sessions for them. Small's journal entry on this date reveals that he was introduced to cupping techniques and acupuncture for rheumatism at the lecture with the barefoot doctors. The doctors encouraged the delegates to combine Western medicine with traditional medicine, including what the Chinese participants referred to as "traditional Black medicine." "There were a million barefoot doctors in China," Small recalls, "and I was inspired by how they integrated Western and Chinese medicine to serve the people." Small is standing, second from the right. At far right is Dennis Hilliard, nephew of then-в P P chief of staff David Hilliard. David Hilliard had invited Small to participate in the delegation. Levinson (standing, third from the left) was nineteen years old on this trip. He returned to Oakland and volunteered with New York acupuncturist Frederick Kao, who was hosting a convention in the Bay Area. Levinson later became a physician, graduating from the University of California San Francisco Medical School in 1981.

Note: David Levinson, in conversation with the author, February 8, 2019. PHOTO TAKEN BY ED SUE 


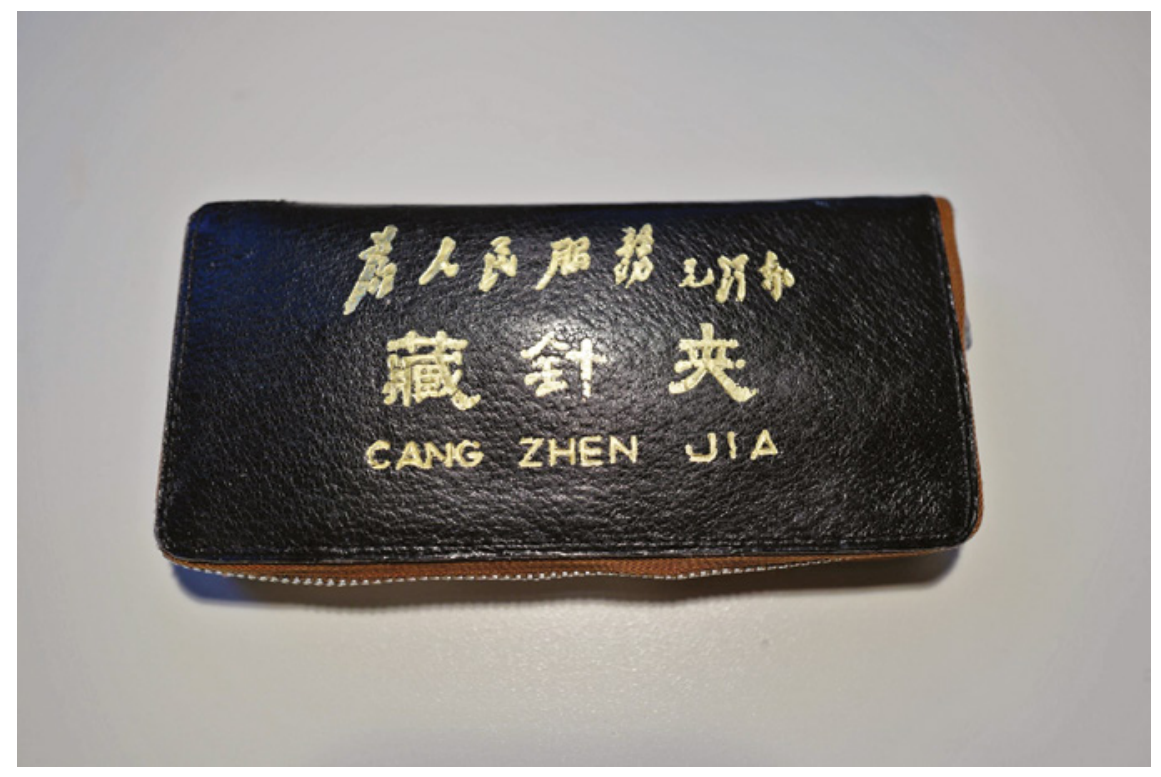

FIGURE 5 March 1972: A purse for holding acupuncture needles (cangzhen jia 藏针夹). The inscription reads: “Serve the People.' Mao Zedong” (wei renmin fuwu Mao Zedong 为人民服务 毛泽东). This particular needle purse was purchased by Levinson. Other members of the group, including Small, purchased identical purses.

After the barefoot doctor lectures, the delegates, intrigued by acupuncture, bought needles and began experimenting on each other. The tour guides saw that the group was interested and, in response, set up more detailed lectures on acupuncture. This highlights the ways in which the delegates, despite following an itinerary crafted by the CCP, were able to influence the course of the trip. PHOTO TAKEN BY THE AUTHOR, SEPTEMBER 10, 2020 


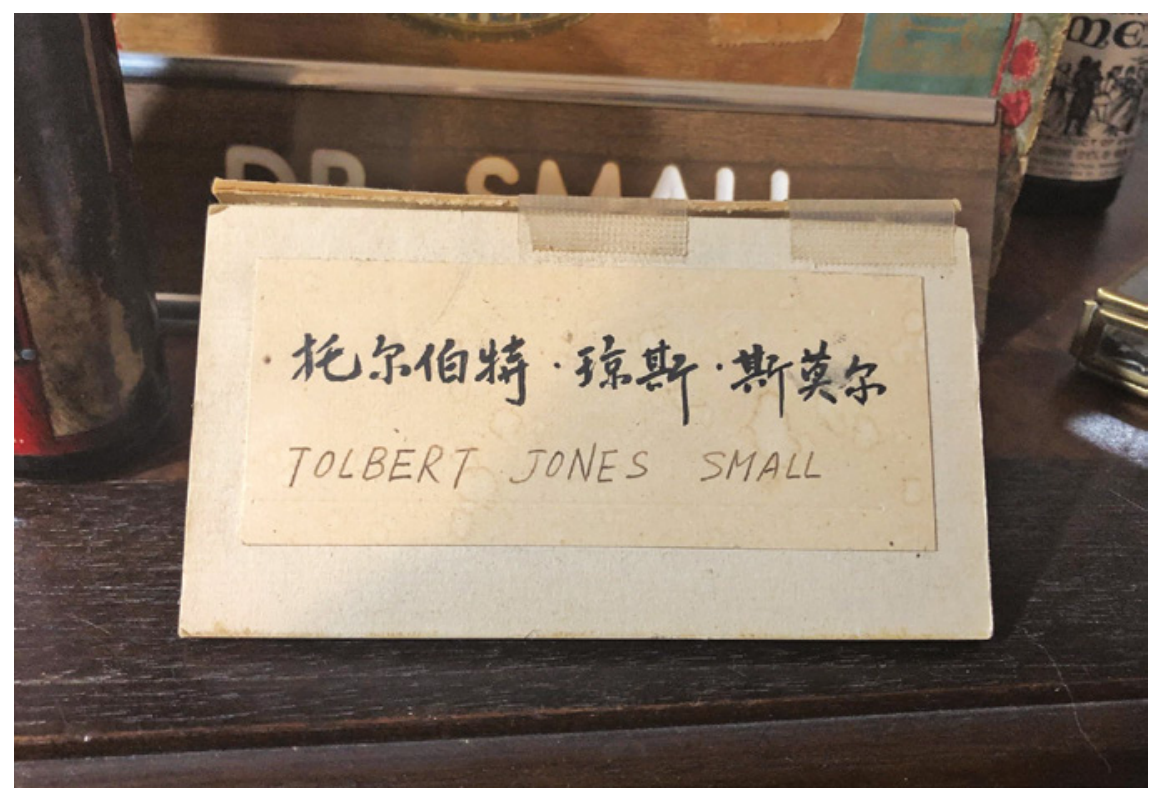

FIGURE 6 March 27, 1972: Small's place card for a dinner at the Great Hall of the People (Renmin dahuitang 人民大会堂) in Beijing. The delegates returned to Beijing on March 26 from Yan'an. On the night of March 27, they attended a banquet with the International Liaison Department of the Central Committee of the Communist Party of China (Zhongguo gongchangdang zhongyang weiyuanhui duiwai lianluo bu 中国共产党中央委员会对外联络部).

PHOTO TAKEN BY THE AUTHOR, OCTOBER 13, 2019 


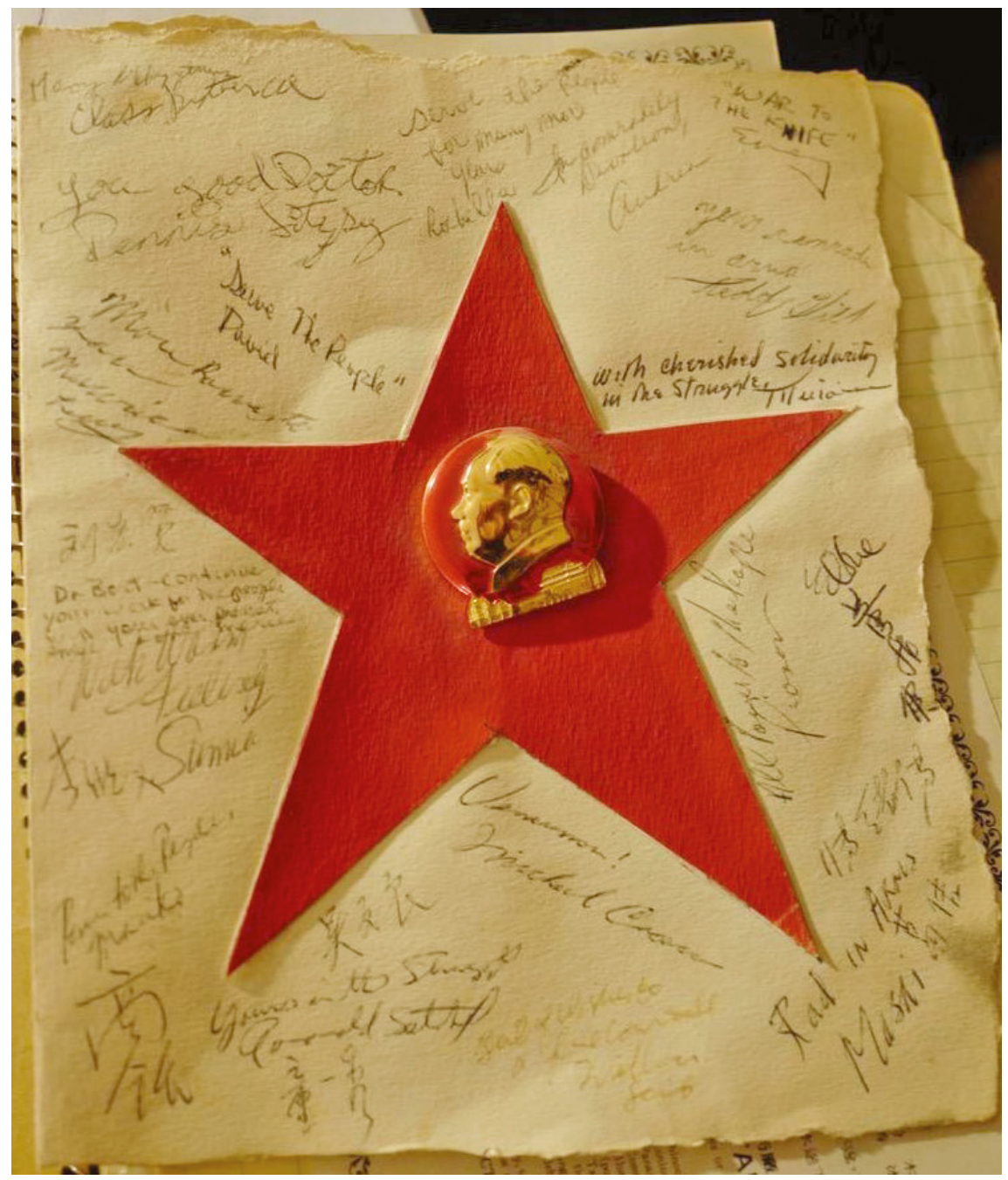

FIGURE 7 April 2, 1972: Small celebrated his thirtieth birthday in Shanghai, where the tour guides set up a birthday party with a cake and balloons. This card was made by other в Р delegates and includes their signatures as well as those of the translators. The delegates formed a close bond with the translators over the course of the trip; Small recalls that "the translators cried when we left!" The inside of the card bears a poem entitled "The Revolutionary Doctor" written by Cherry. Remarking on the insignia of Mao, Small states: "Like many figures, Mao did some good and did some bad. Like Huey [Newton]." PHOTO TAKEN BY THE AUTHOR, FEBRUARY 9, 2019 


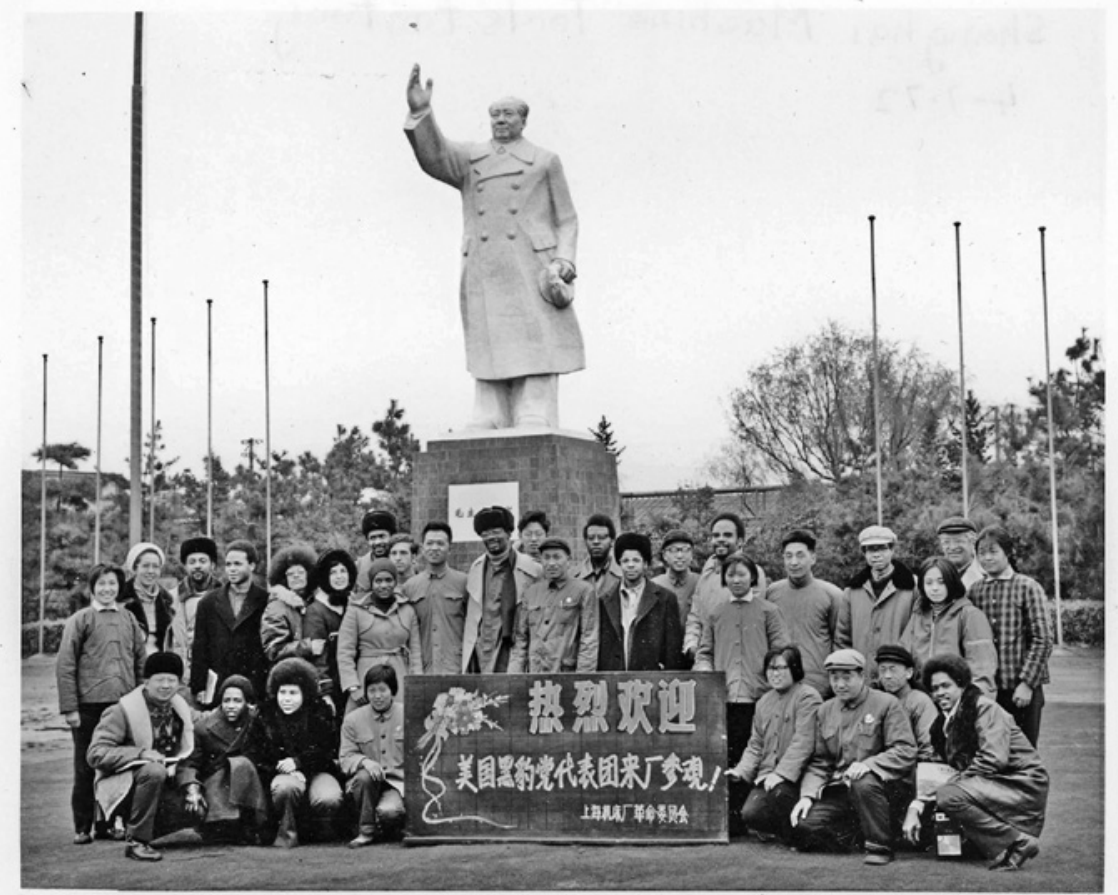

FIGURE 8 April 7, 1972: The delegates at the Shanghai Machine Tools Factory. The banner reads: "Warmest Welcome to the American Black Panther Party Delegation to Our Factory!" (relie huanying Meiguo Heibaodang daibiaotuan lai guang canguan 热烈欢迎美国黑豹党代表团来厂参观). It is signed: “Revolutionary

Committee of the Shanghai Machine Tools Factory" (Shanghai jichuangguang geming weiyuanhui 上海机床厂革命委员会). Small is in the furthest back row, to the immediate left of the Mao statue. Hewitt, the minister of education for the В Р at the time and the de facto leader of the delegation, stands directly in front of the statue placard identifying Mao. Douglas, the minister of culture for the в РР, pictured here wearing dark-shaded glasses and a tan coat, is the seventh from the right, standing.

Note: See Douglas 2007.

PHOTO TAKEN BY CCP TOUR GUIDE 


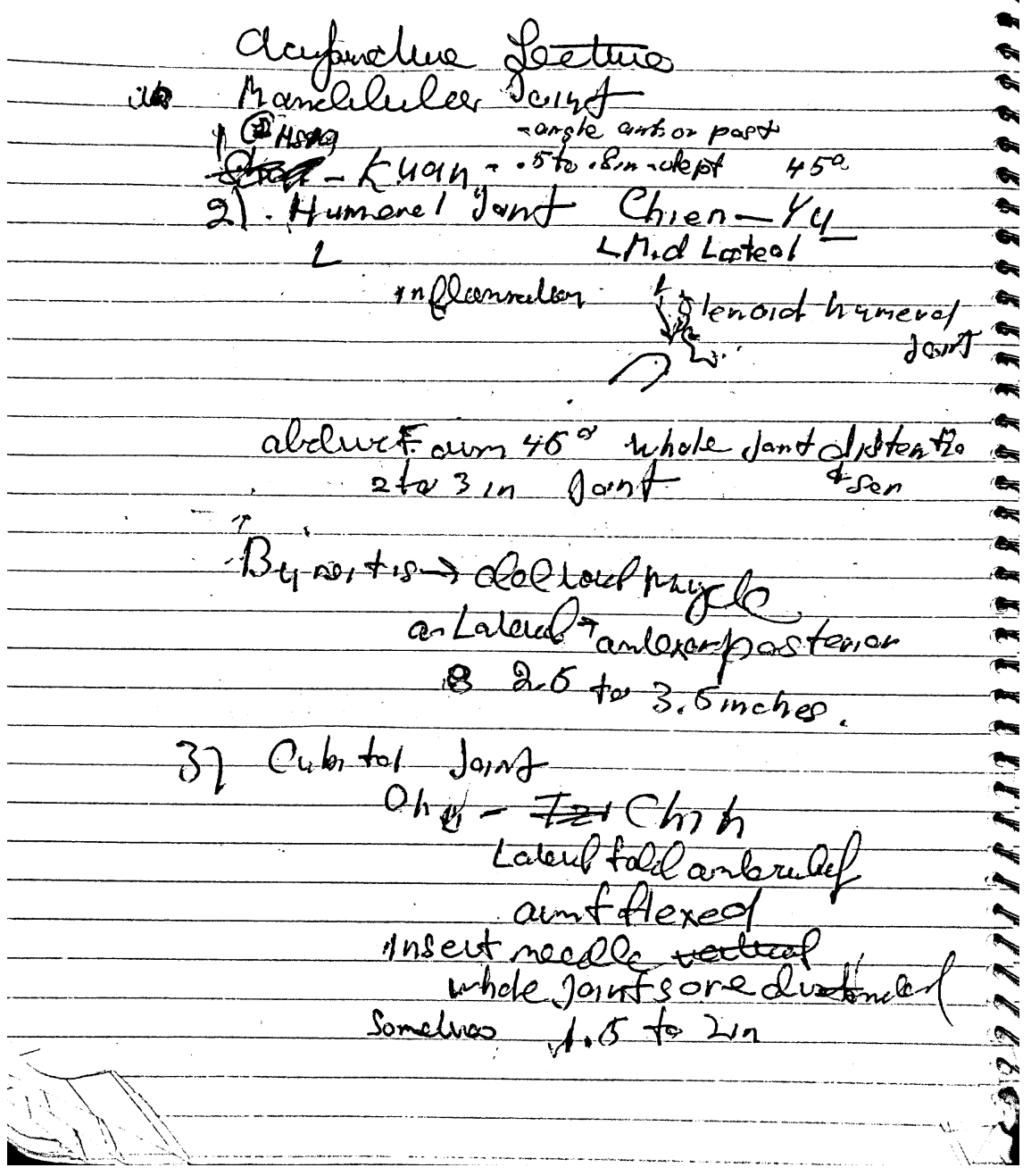

FIGURE 9 April 7, 1972: A page from the journal Small kept during the delegation (depicted in Figure 1). It records lecture notes on the presentation of a $\mathrm{Dr}$. Wu on acupuncture to the delegates in Shanghai. SCAN BY THE AUTHOR, AUGUST 20, 2019 


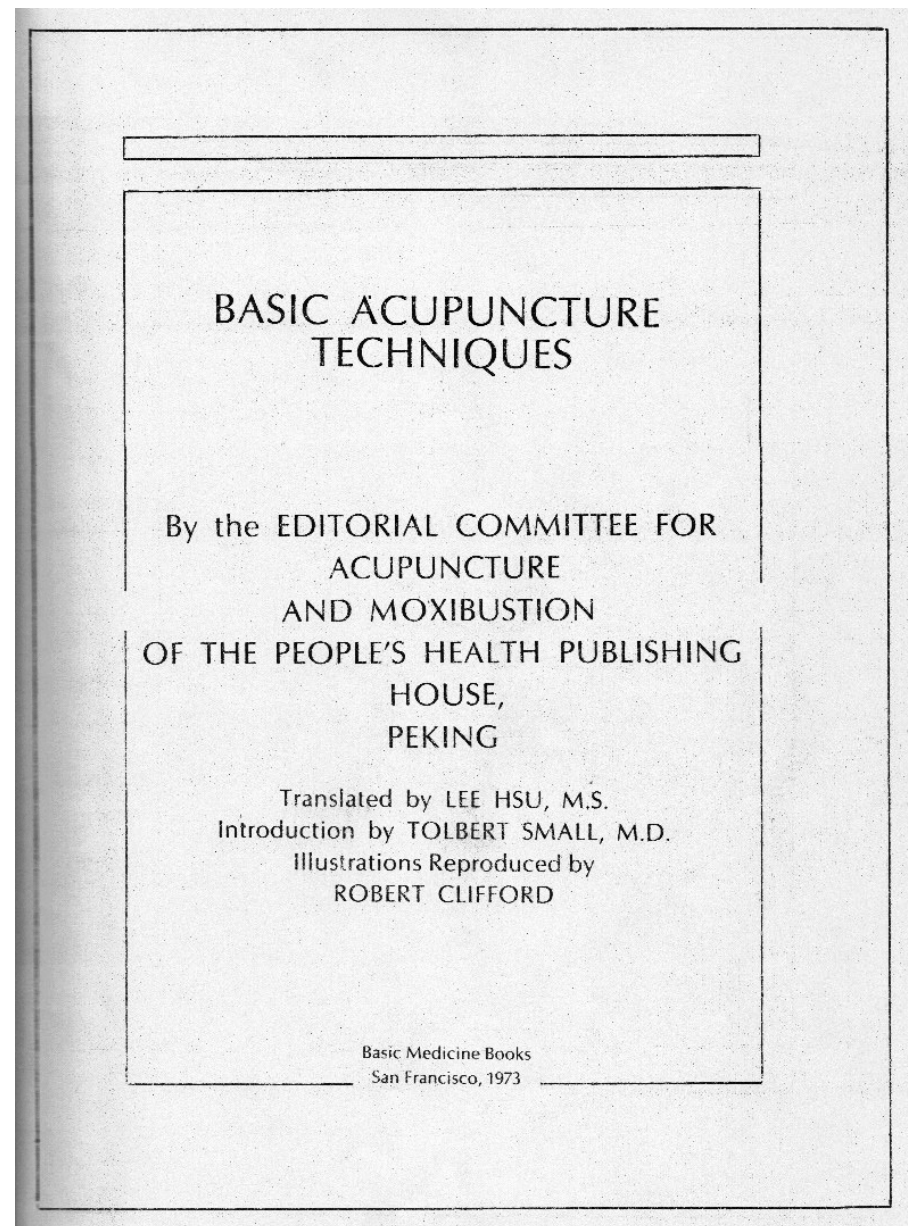

FIGURE 10 1973: After Small returned home from China, he pursued his interest in acupuncture by experimenting on himself, needling various points on his body according to graphs and texts he had brought back from his trip. "The barefoot doctors did a lot of acupuncture on themselves, so I thought I could do it too," Small explains. He often practiced after hours at the BPP's George Jackson People's Free Medical Clinic, where he was the medical director, and he encouraged others to join him. One attendee was David Bacon, a photographer and volunteer at the clinic, who had only heard of acupuncture before, but was now able to see it in action and use it personally. "Doing acupuncture at the clinic felt like an important political act," Bacon emphasizes. Feeling tangible 
results from his practice, Bacon was inspired to make acupuncture more widely known. At China Books in San Francisco, he found a copy of Zhongguo zhenjiuxue gaiyao 中国针炎学概要 (lit., Essentials of the Study of Chinese Acupuncture) published in 1964 by Renmin weisheng chubanshe 人民卫生出版社 (People's Medical Publishing House). Bacon commissioned an English translation of the book from Lee Hsu, a Chinese physicist and mathematician, and they gave it the title Basic Acupuncture Techniques. At Bacon's request, Small wrote the introduction, which included a summary of acupuncture research in China and an overview of acupuncture's utility in practice. Small (along with Bacon, Hsu, and another Chinese-born mathematician, Kwan-shei Chen) also served on the editorial committee for Basic Medicine Books, a nonprofit organization that Bacon had established to disseminate knowledge of Chinese medical practices to a broader American audience. Basic Acupuncture Techniques was the first of a number of books Basic Medicine Books aimed to publish. Unfortunately, due to limited funds and a lack of wider support, its goals did not come to fruition. Small believes Basic Acupuncture Techniques may have been the earliest English translation of this text, which would later be translated by the Foreign Language Press in Beijing in 1975 and published under the title Essentials of Chinese Acupuncture.

During the 1970s, Small also had weekly acupuncture sessions with his friend Alex Feng, which launched Feng's subsequent career as an acupuncturist. Small would later teach acupuncture to his physician assistants at the clinic cofounded with Anola Price Small in 1980 (see Figure 13) and throughout his career he also taught acupressure to a number of his patients. He would consistently and primarily refer back to Basic Acupuncture Techniques as the basis of his teachings and practice.

Note: David Bacon, email correspondence with the author, June 18, 2021. Quoted with permission.

SCAN BY THE AUTHOR, MARCH 30, 2021 


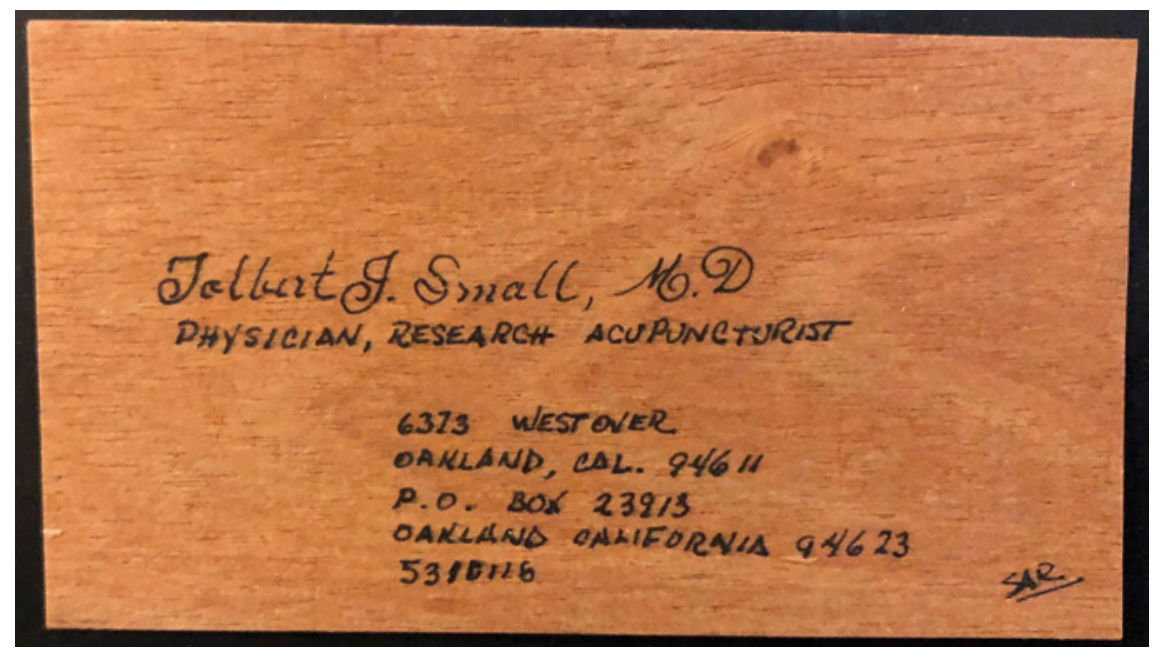

FIGURE 11 1974: A wooden business card that reads, "Tolbert J. Small, M.D / PHYSICIAN, RESEARCH ACUPUNCTURIST." Four of these cards were made in Mexico by a female artist with the initials SAR, who was renting out a room in the home of Mireya Cueto, a Mexican puppeteer. Small and his wife at the time, Anola Price Small, visited Mexico City in 1974, where they met the Cueto family through mutual friends. During this trip Small treated Lola Cueto - mother of Mireya and an artist in her own right - for knee pain with acupuncture. "SAR" offered to make these business cards for Small. "She wrote 'research acupuncturist' because it was illegal to practice acupuncture in California unless you were doing it for research," Small recalls. The same year that these cards were made, Small published two papers - "The Neurophysiological Basis for Acupuncture" and "Acupuncture Anesthesia: A Review" - in the American Journal of Acupuncture. Motivated by his own curiosity and in response to patient requests, he continued to keep abreast of developments in acupuncture research throughout his career, on conditions as varied as hypertension, fibromyalgia, depression, and asthma.

PHOTO TAKEN BY THE AUTHOR, OCTOBER 13, 2019 


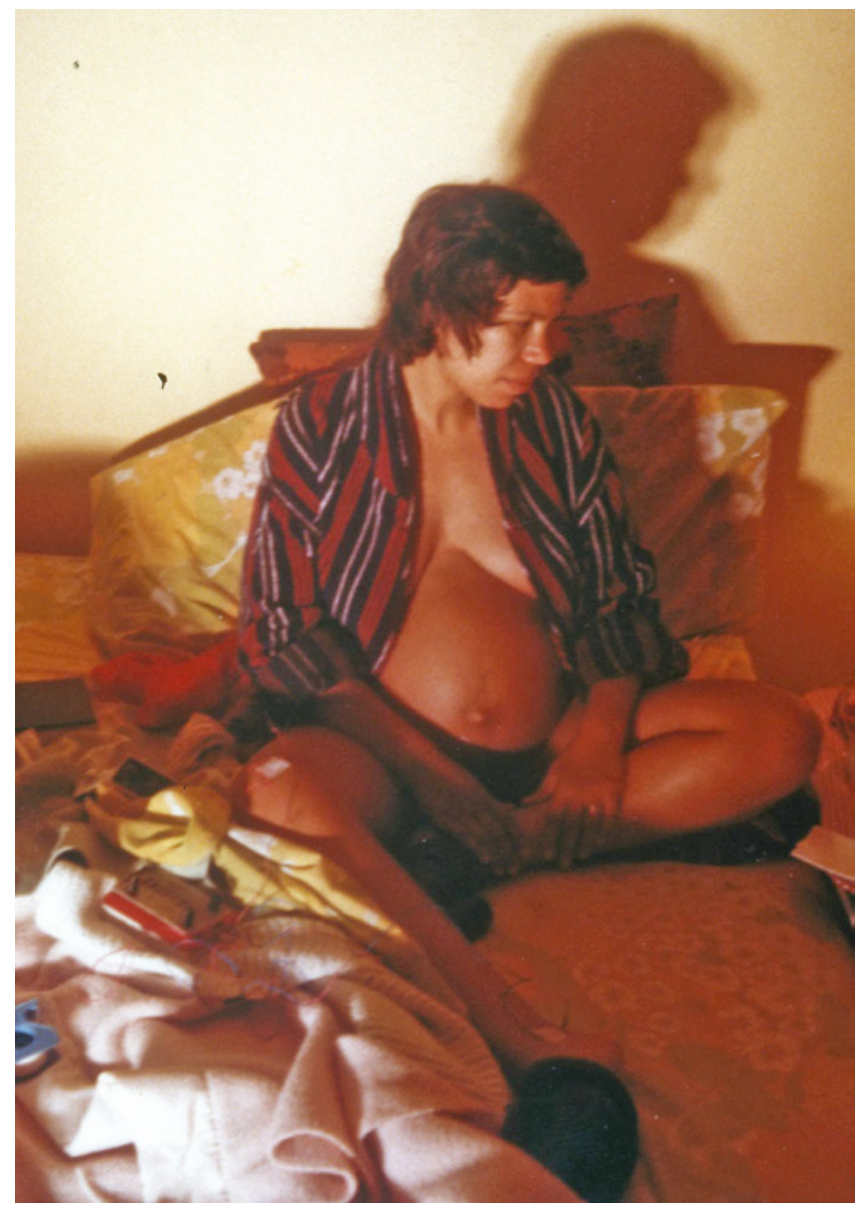

FIGURE 12 June 23, 1975: Anola Price Small, a registered nurse, and then-wife of Tolbert, in labor during the birth of her second child, Ayanna. Tolbert treated her with acupuncture to manage labor pains during the birth of their children. In this picture, she has acupuncture needles inserted into her right knee. They are connected to an electrostimulation machine resting on the white blanket near her knee. Anola received a Bachelor of Arts degree in African American studies from Stanford University in 1975 and subsequently earned a Bachelor of Science degree in nursing from the University of California, San Francisco, in 1979 and a Master of Public Policy in healthcare policy from the University of California, Berkeley, in 1995. She co-owned the private medical clinic she opened with Tolbert in 1980 and managed its operations while also working as a revenue and healthcare analyst for San Francisco General Hospital and later the Alameda County Medical Center.

PHOTO TAKEN BY TOLBERT SMALL 


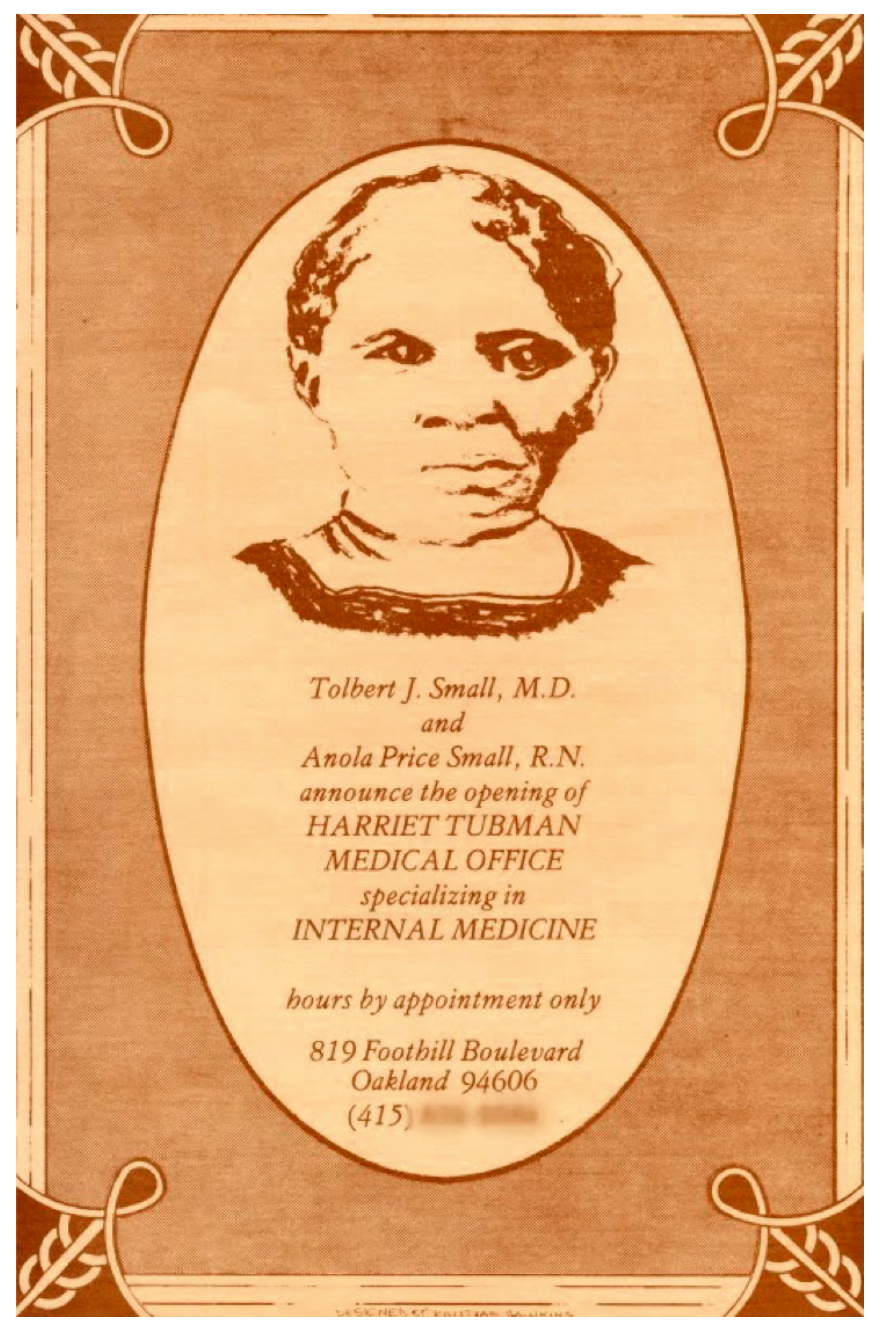

FIGURE 13 1980: The Smalls opened the Harriet Tubman Medical Office in 1980 in Oakland, California. Chosen by Anola, the name of the clinic honored Harriet Tubman (1822-1913), who freed herself from slavery and went on to become one of the most effective "conductors" of the Underground Railroad, the secret networks that African Americans enslaved in the American South used to escape to the Northern free states and Canada. Tubman led more than a dozen missions, helping to free over seventy enslaved persons. The Smalls treated several thousand patients at this office over the decades, using a combination of Western and Chinese medicine. The clinic remained in operation until 2016, when it closed due to financial difficulty. This photograph has been modified to conceal the phone number.

SCANNED IMAGE COURTESY OF TOLBERT SMALL 


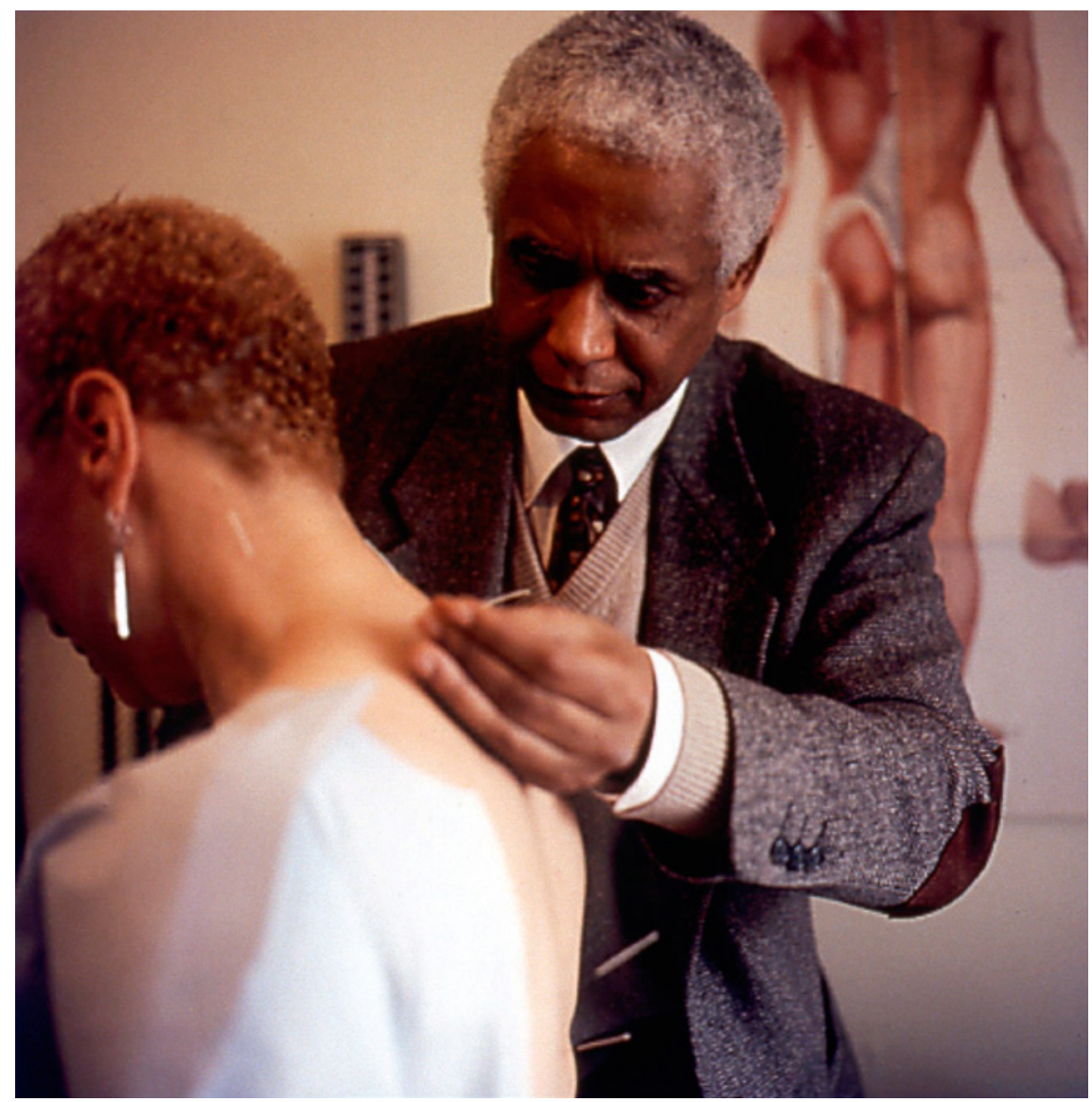

FIGURE 141993 or 1994: Small performing acupuncture on a patient with neck and back pain at the Harriet Tubman Medical Office. This was taken in the upstairs room, which was dedicated to acupuncture. As much as possible, Small treated patients suffering from acute and chronic pain with acupuncture. "A lot of people, including myself, do not want to use drugs for their pain, so I try to decrease their prescriptions and use acupuncture," Small recalls. He also showed a number of patients how to perform the acupuncture on themselves, supervising them on how to needle the primary relevant points. In the barefoot doctors' style, there was a simplified protocol the patients could perform themselves.

PHOTOGRAPHER UNKNOWN. PHOTO COURTESY OF TOLBERT SMALL 

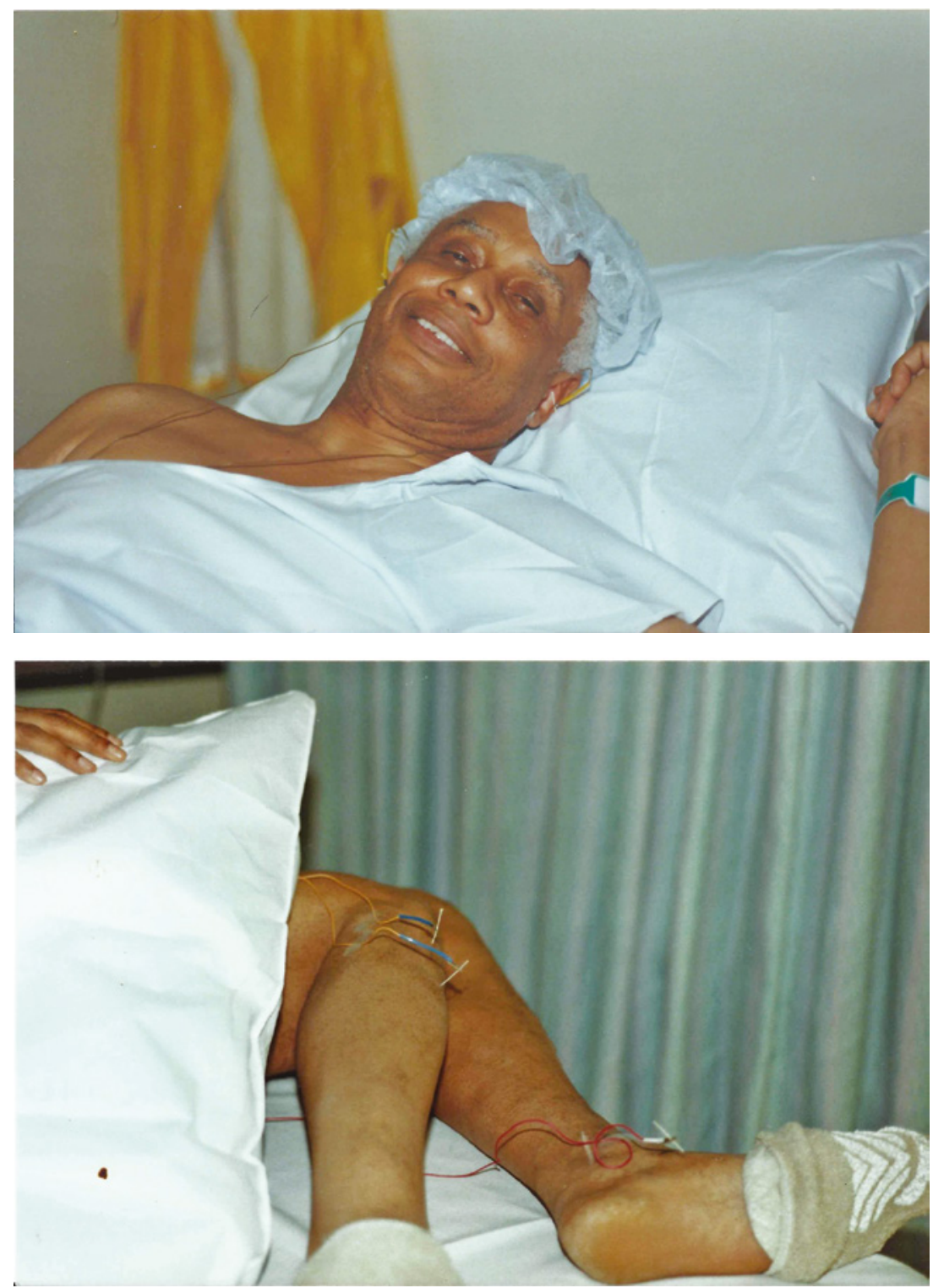

FIGURES 15 AND 16 June 23, 1998: Just as Small tried acupuncture points on himself during his trip to China and upon his return to the Bay Area, he continued to use his own body for clinical experimentation throughout his career. These photographs show Small at his local hospital in Oakland, California, performing acupuncture anesthesia with electrostimulation on himself during a colonoscopy. He created a unique protocol based on his research on a number of articles on acupuncture anesthesia.

PHOTOS TAKEN BY ANOLA PRICE SMALL 


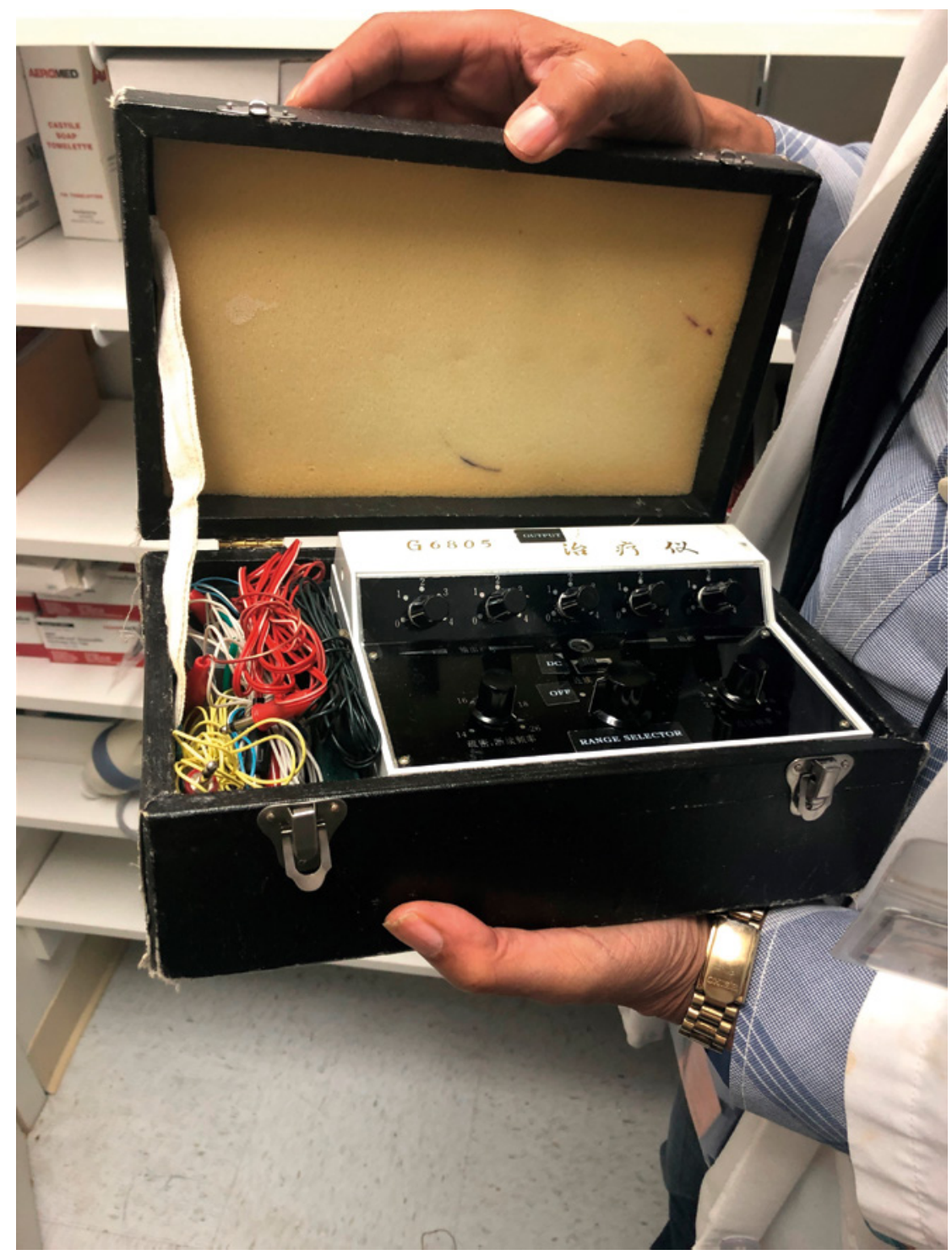

FIGURE 17 August 26, 2019: Small at the Native American Health Center in San Francisco, California, holding an electrostimulation machine for acupuncture, which he acquired in Shanghai on his 1972 trip. Other friends who visited China subsequently brought him back more recent models. In later decades, Small was able to order additional machines directly from suppliers, including from Electro-Therapeutic Devices (now opIs Supplies) in Markham, Ontario, Canada. Small estimates that he performs electrical stimulation 95 percent of the time when he uses acupuncture for patients, as they have reported more pain relief this way than with manual needle manipulation. PHOTO TAKEN BY THE AUTHOR, AUGUST 26, 2019 


\section{Acknowledgments}

I am very grateful to Yi-Li Wu and Daniel Burton-Rose for inviting me to contribute to this important issue of Asian Medicine, and for their time, efforts, and thoughtful intention. My gratitude, as always, to my interlocutors, and especially Dr. Tolbert Small; I am lucky to work with them.

\section{About the Author}

Eana Meng is a MD-PhD candidate at Harvard Medical School and the Department of History of Science at Harvard University. Her interests include the histories of complementary and alternative medicines. She has produced a video series and published articles on the revolutionary roots of American acupuncture and its global legacies.

\section{Bibliography}

Atkins, Gary. 1972. "Local Panther Group Runs 'Survival Programs'” The Stanford Daily 161, no. 2 (February 2, 1972). Transcribed and edited by Paul Saba. Encyclopedia of Anti-Revisionism On-Line. Reproduced at https://www.marxists.org/history/erol/ ncm-1a/panther-program.htm.

Burton-Rose, Daniel, and Yi-Li Wu. 2021. "Acupuncture, the Black Panther Party, and People's Medicine: An Interview with Physician-Activist Tolbert Small." Asian Medicine 16, no. 2: 251-75.

Douglas, Emory. 2007. Black Panther: The Revolutionary Art of Emory Douglas. Edited by Sam Durant. New York: Rizzoli International Publications.

Meng, Eana. 2021. "Reflections on(Re)making History:African American Acupuncturists and the Archives of Tolbert Small." Asian Medicine 16, no. 2: 295-309.

"A Taste of Power': The Woman Who Led the Black Panther Party." 2015. Longreads, May 2, 2015. https://longreads.com/2015/o3/o3/a-taste-of-power-the-woman-who -led-the-black-panther-party/. 